\begin{tabular}{|l|l|l||}
\hline \multicolumn{2}{|c|}{ PublisherInfo } \\
\hline \hline PublisherName & $:$ & BioMed Central \\
\hline \hline PublisherLocation & $:$ & London \\
\hline \hline PublisherImprintName & $:$ & BioMed Central \\
\hline \hline
\end{tabular}

\title{
Linking replication and transcription
}

\begin{tabular}{|l|c|l||}
\hline \multicolumn{2}{|c|}{ ArticleInfo } \\
\hline \hline ArticleID & $:$ & 4605 \\
\hline \hline ArticleDOI & $:$ & $10.1186 /$ gb-spotlight-20021009-01 \\
\hline \hline ArticleCitationID & $:$ & spotlight-20021009-01 \\
\hline \hline ArticleSequenceNumber & $:$ & 271 \\
\hline \hline ArticleCategory & $:$ & Research news \\
\hline ArticleFirstPage & $:$ & 1 \\
\hline \hline ArticleLastPage & $:$ & 2 \\
\hline \hline & & RegistrationDate : 2002-10-9 \\
\hline ArticleHistory & $:$ & OnlineDate \\
\hline \hline ArticleCopyright & $:$ & BioMed Central Ltd2002-10-9 \\
\hline \hline ArticleGrants & $:$ & \\
\hline \hline ArticleContext & $:$ & 130593311 \\
\hline \hline
\end{tabular}




\section{Jonathan B Weitzman}

Email: jonathanweitzman@hotmail.com

There has been much speculation about the relationship between replication timing and gene expression in eukaryotes. In an Advanced Online Publication in Nature Genetics, Schübeler et al. describe how they used microarray hybridization experiments to construct a replication timing map for the entire Drosophila melanogaster genome (Nature Genetics, 30 September 2002, doi:10.1038/ ng1005). They labeled Drosophila cell cultures with BrdU (bromodeoxyuridine triphosphate) and used flow cytometry to sort cells into different cell-cycle fractions. They then immunoprecipitated labeled DNA with anti-BrdU antibodies and PCR-amplified associated DNA fragments, before hybridization to DNA microarrays to compare material from early or late stages of S phase. They found that neighboring genomic regions were replicated at similar times during $\mathrm{S}$ phase. They processed the data to generate a genome-wide profile of replication. They found that pericentromeric heterochromatin replicates late in $\mathrm{S}$ phase. They compared gene-expression status and replication timing for over $40 \%$ of the fly genome and found a high correlation. These results contrast with a previous study in yeast, suggesting that the link between transcription and replication timing may be unique to higher eukaryotes.

\section{References}

1. The control of mammalian DNA replication: a brief history of space and timing.

2. Nature Genetics, [http://www.nature.com/ng]

3. Replication dynamics of the yeast genome. 